СТАТЕВО-ВІКОВІ ОСОБЛИВОСТІ АТЕРОСКЛЕРОТИЧНОГО УРАЖЕННЯ ВІНЦЕВИХ АРТЕРІЙ У ПАЦІСНТІВ ЗІ СТАБІЛЬНОЮ ІШЕМІЧНОЮ ХВОРОБОЮ СЕРЦЯ БЕЗ ПЕРЕНЕСЕНОГО ІНФАРКТУ МІОКАРДА B AHAMHEЗI

\title{
I.A. Свінціцький
}

Національний медичний університет імені О.О. Богомольця, м. Київ, Україна

Ключові слова: стабільна ішемічна хвороба атеросклероз, стать, вік.

Буковинський медичний вісник. Т.21, № 3 (83). C. $75-82$

DOI:

10.24061/2413-0737.

XXI.3.83.2017.98

E-mail: igor.svintsitskyi @nти.иа серия, коронарний

Мета роботи - визначити статево-вікові особливості стану віниевого русла в пацієнтів зі стабільною ішемічною хворобою серия без перенесеного інфаркту міокарда в анамнезі.

Матеріал і методи. В одноцентровому крос-секційному дослідженні проаналізовано дані обстеження 118 хворих на стабільну ішемічну хворобу серия (чоловіків - 70 (59,3\%), жінок - 48 (40,7 \%), медіана віку - 65 років), яких за статевим принципом було розподілено на дві групи. Усім пачієнтам проводили загальноклінічні, антропометричні, лабораторні обстеження і коронарографію.

Результати. У чоловіків відзначалися більш виражені зміни вінцевого русла (за кількістю уражених судин і показником Gensini score) порівняно із жінками, причому це твердження було справедливе в обох вікових категоріях: до і понад 65 років. У них частіше спостерігався множинний коронарний атеросклероз $(28,6 \%$ vs $8,3 \%, p<0,01)$, тоді як в осіб жіночої статі - інтактні судини $(39,6 \%$ vs $10 \%, p<0,001)$. За локалізачією гемодинамічно вагомих змін вінцевих артерій статистично значущих відмінностей серед представників обох статей не відзначалося: $i$ в чоловіків, $i$ в жінок найчастіше обструкиія виникала в передній міжшлуночковій гілці лівої вінцевої артерії, переважно в проксимальній ї̈ частині.

Висновок. Жіночий патерн стабільної ішемічної хвороби серия характеризується частою відсутністю обструктивного ураження вінцевих артерій, поступовим прогресуванням атеросклеротичних змін вінцевого русла з віком, однак локалізачія гемодинамічно вагомих звужень не відрізняється від такої у хворих чоловічої cmami.

ВОЗРАСТНЫЕ И ПОЛОВЫЕ ОСОБЕННОСТИ

Ключевые слова: стабильная ишемическая болезнь сердиа, коронарный атеросклероз, пол, возраст.

Буковинский медиџинский весник. T.21, № 3 (83). C. $75-82$

\section{АТЕРОСКЛЕРОТИЧЕСКОГО ПОРАЖЕНИЯ КОРОНАРНЫХ АРТЕРИЙ У ПАЦИЕНТОВ СО СТАБИЛЬНОЙ ИШЕМИЧЕСКОЙ БОЛЕЗНЬЮ СЕРДЦА БЕЗ ПЕРЕНЕСЕННОГО ИНФАРКТА МИОКАРДА В АНАМНЕЗЕ \\ И.А. Свинцицкий}

Цель работы - изучить возрастные и половые особенности состояния коронарного русла у пациентов со стабильной ищемической болезнью сердиа без перенесенного инфаркта миокарда в анамнезе.

Материал и методы. В одноцентровом кросс-секиионном исследовании проанализированы данные обследования 118 больных стабильной ишемической болезнью сердиа (мужчин - 70 (59,3\%), женщин - 48 (40,7\%), медиана возраста - 65 лет), которые по половому принципу были разделены на две группы. Все пациенты прошли общеклиническое обследование с проведением антропоме- 
трических измерений, лабораторных исследований, а также коронарографии.

Результаты. У мужчин отмечались более выраженные изменения коронарного русла (по количеству пораженных сосудов и показателю Gensini score) по сравнению с женщинами, причем это утверждение было справедливо в обеих возрастных категориях: до и свыше 65 лет. У них чаще регистрировался множественный коронарный атеросклероз (28,6\% vs 8,3\%, p <0,01), тогда как у лии женского пола - интактные сосуды (39,6\% vs $10 \%$, $p<0,001)$. По локализачии гемодинамически значимых стенозов коронарных артерий статистически значимых различий среди представителей обоих полов не отмечалось: и у мужчин, и у женщин чаще всего обструкиия возникала в передней межжелудочковой ветви левой коронарной артерии, преимущественно в проксимальной ее части.

Вывод. Женский паттерн стабильной ишемической болезни сердиа характеризуется частым отсутствием обструктивного поражения коронарных артерий, постепенным прогрессированием атеросклеротических изменений коронарного русла с возрастом, однако локализачия гемодинамически значимых сужений не отличается от таковой у больных мужского пола.

Key words: stable ischemic heart disease, coronary atherosclerosis, sex, age.

Bukovinian Medical Herald. T.21, № 3 (83). P. $75-82$

\section{AGE AND SEX-RELATED FEATURES OF CORONARY ATHEROSCLEROTIC LESIONS IN PATIENTS WITH STABLE ISCHEMIC HEART DISEASE AND NO HISTORY OF MYOCARDIAL INFARCTION}

\section{I.A. Svintsitskyi}

The objective of this study was to determine age and sex-related features of coronary atherosclerotic lesions in patients with stable ischemic heart disease and no history of myocardial infarction.

Material and methods. We performed a single-center cross-sectional study of 118 patients with stable ischemic heart disease (70 (59,3\%) men and 48 (40,7\%) women, median age - 65 years) who were divided into two groups according to sex criterion. All patients underwent complete evaluation including anthropometric/clinical assessment, laboratory tests and coronary angiography.

Results. More severe atherosclerotic changes in the epicardial coronary arteries (greater number of affected vessels and higher Gensini score) were detected in men, this statement was true in both age categories: under and over 65 years. They were more likely to have multivessel disease $(28,6 \%$ vs $8,3 \%, p<0,01)$, while normal coronary arteries were more common in women $(39,6 \%$ vs $10 \%, p<0,001)$. There were no statistically significant differences among the representatives of both sexes in the topography of significant coronary stenoses: in both men and women obstruction usually occurred in the left anterior descending artery, mainly in its proximal part.

Conclusion. The female pattern of stable ischemic heart disease is characterized by frequent absence of obstructive coronary lesions, agerelated gradual progression of atherosclerotic changes, but the localization of coronary stenoses does not differ in men and women. 
Original research

Вступ. Актуальність проблеми ішемічної хвороби серця (IXC) не викликає жодних сумнівів як в Україні, так і в багатьох країнах світу, адже саме вона вже протягом багатьох років незмінно залишається головною причиною інвалідності та смертності працездатного населення [1].

Проведення широкомасштабних профілактичних заходів, раннє виявлення захворювання та своєчасне ефективне лікування є ключем до успіху в боротьбі з ним, при цьому неодмінно мають враховуватися статево-вікові особливості розвитку і перебігу IXC $[2,3]$. Сьогодні вже став очевидним той факт, що наявні раніше уявлення про цю патологію, що базувалися на результатах клінічних досліджень за участю пацієнтів переважно чоловічої статі, не віддзеркалюють реальної клінічної практики $[4,5]$. Жінки становлять особливу групу хворих, в яких ознаки IXC, як багатофакторного захворювання, представлені найбільш чітко $[6,7]$. Крім того, у них спостерігається варіативність клінічної картини, вираженіше зниження працездатності та більш несприятливий порівняно з чоловіками прогноз $[8,9]$. Все вищенаведене обгрунтовує необхідність подальшого глибокого та всебічного вивчення жіночого патерну вказаної патології [10].

Мета роботи. Визначити статево-вікові особливості стану вінцевого русла в пацієнтів зі стабільною ішемічною хворобою серця без перенесеного інфаркту міокарда в анамнезі.

Матеріал і методи. В одноцентровому кроссекційному дослідженні, проведеному на базі ДУ «Інститут серця МО3 України», проаналізовано дані обстеження 118 хворих на стабільну IXC (чоловіків - 70 (59,3 \%), жінок - 48 (40,7 \%)), яких за статевим принципом було розподілено на дві групи. Медіана віку пацієнтів становила 65 (IQR: 58-70) років.

Критерії залучення до дослідження: вік $\geq 18$ років, наявність документованої стабільної IXC.

Критерії вилучення із дослідження: перенесений інфаркт міокарда (IM) в анамнезі, хронічна серцева недостатність ІІБ-ІІІ стадії за класифікацією Стражеска-Василенка, гостре порушення мозкового кровообігу, ревматична лихоманка, міокардит, перикардит, природжені та набуті вади серця, гостре пошкодження нирок, тяжка печінкова недостатність, автоімунні системні хвороби, злоякісні онкологічні захворювання, виражені ментальні порушення, а також інша патологія, яка могла б суттєво вплинути на результати дослідження.

Діагноз IXC встановлювали на основі відповідних рекомендацій Європейського товариства кардіологів [11] і Уніфікованого клінічного протоколу первинної, вторинної (спеціалізованої) та третинної (високоспеціалізованої) медичної допомоги «Стабільна ішемічна хвороба серця» [12].

У всіх пацієнтів виявлено стабільну стенокардію напруження: I функціонального класу
(ФК) - в 1 (0,8 \%) особи, ІІ ФК - у 74 (62,8 \%), III ФК - у $41(34,7 \%)$, IV ФК - в $1(1,7 \%)$. У 117 $(99,2$ \%) обстежених зареєстровано хронічну серцеву недостатність (І ст. - у 43, IIА ст. - у 74), у $116(98,3 \%)$ - гіпертонічну хворобу, у 33 (28\%) - фібриляцію передсердь (пароксизмальну - у 12, персистивну - у 8, постійну - у 13), у 46 (39 \%) цукровий діабет, у 69 (58,5 \%) - ожиріння (І ст. у 48, II ст. - у 15, III ст. - у 6), у 39 (33,1 \%) осіб надлишкову масу тіла.

Усім пацієнтам виконували загальноклінічні, антропометричні та лабораторні (загальний і біохімічний аналізи крові, загальний аналіз сечі) обстеження.

Коронарографію проводили за допомогою двопланової рентгенівської ангіографічної системи 3 плоскими детекторами «Axiom Artis dBC» (Siemens, Федеративна Республіка Німеччина) за методикою M. Judkins (1967). При аналізі даних оцінювали локалізацію, ступінь і кількість звужень вінцевих артерій (BА). Гемодинамічно значущим (обструктивним) ураженням вважали стенозування просвіту судини понад $50 \%$. Вагоме звуження основного стовбура лівої вінцевої артерії (ЛВА) розцінювали як ураження двох ВА. У 26 (22 \%) пацієнтів було виявлено інтактні ВА, у 18 $(15,3 \%)$ - гемодинамічно незначущі стенози, у $29(24,6 \%)$ - односудинне ураження, у 21 (17,8 \%) - двосудинне ураження, у 24 (20,3\%) багатосудинне ураження ВА.

Кількісне оцінювання ступеня ураження вінцевого русла здійснювали за допомогою інтегрального показника - Gensini score (GS), що є сумою добутків індексу тяжкості стенозу й індексу функціонального значення кожного сегмента ВА:

- індекс тяжкості стенозу визначається відповідно до відсотка звуження просвіту ВА в місці бляшки (1-25\% - 1 б., 26-50\% - 2 б., 51-75\%- 4 б., 76-90\% - 8 б., 91-99\%16 б., $100 \%$ - 32 б.);

ється за локалізацією стенозу: основний стовбур (ОС) ЛВА - 5 б., проксимальні сегменти передньої міжшлуночкової гілки (ПМШГ) і огинальної гілки (ОГ) ЛВА - по 2,5 б., середні сегменти ПМШГ ЛВА і ОГ ЛВА - по 1,5 б., права вінцева артерія (ПВА), дистальні сегменти ПМШГ ЛВА і ОГ ЛВА, крайова гілка огинальної артерії (КГОА), перша діагональна гілка (ДГ) ЛВА, задня міжшлуночкова гілка (ЗМШГ) ПВА - по 1 б., інші сегменти - по 0,5 б. [13].

Значення GS від 1 до 32 балів свідчили про помірне ураження вінцевого русла, а понад 32 бали - про тяжке.

Статистичний аналіз отриманих даних проводили за допомогою програмного середовища $\mathrm{R}$ (версія 3.3.2). Перевірку нормальності розподілу досліджуваних параметрів оцінювали візуально 


\section{Оригінальні дослідження}

при побудові гістограм, а також за допомогою Wкритерію Шапіро-Вілка. Порівняння більшості безперервних значень у двох незалежних групах здійснювали за допомогою U-критерію МаннаВітні, оскільки їх розподіл відрізнявся від нормального, а порівняння абсолютної та відносної частот номінальних і порядкових ознак - за таблицями спряження з оцінкою критерію $\chi^{2}$, у випадках його математичної нестійкості - за таблицями формату « $2 \times 2 »$ та оцінкою значущості точного критерію Фішера. Кількісні дані представлено як Me (IQR), де Me - медіана, IQR - міжквартильний інтервал (перший і третій квартилі), а якіснi $-\mathrm{n}(\%)$.

Усі статистичні методи аналізу та розраховані показники оцінювали при заданому граничному рівні похибки першого роду $(\alpha)$ не вище $5 \%$ $\mathrm{p}<0,05$.

Результати дослідження та їх обговорення. Аналіз демографічних, антропометричних, клініко-анамнестичних і лабораторних даних у порівнюваних групах хворих на стабільну IXC без перенесеного IM в анамнезі виявив, що вони не відрізнялися за більшістю показників, окрім статистично значуще вищих рівнів індексу маси тіла $(\mathrm{p}=0,022)$ у жінок і ФК стенокардії напруження $(\mathrm{p}=0,006)$ у чоловіків (табл. 1$)$.

За даними коронарографії, у чоловіків відзначалося більш тяжке ураження вінцевого русла порівняно із жінками. Так, у них статистично значуще частіше реєструвався множинний коронарний атеросклероз (28,6 \% vs 8,3\%, p<0,01), тоді як в осіб жіночої статі ангіографічні зміни переважно були відсутні (39,6 \% vs $10 \%$, $\mathrm{p}<0,001)$ (табл. 2). Загалом у чоловічій популяції обструктивне звуження ВА спостерігалося суттєво частіше, ніж у жіночій (78,6 \% vs 39,6\%, $\mathrm{p}<0,001)$, що цілком узгоджується з даними зарубіжних авторів [14, 15].

Підсумком кількісного оцінювання ступеня ураження вінцевого русла за допомогою індексу GS стало підтвердження висновку про більш виражений коронарний атеросклероз у чоловіків (13 (5-44) vs 4 (0-16), p <0,001). Так, саме у них тяжке ураження виявлялося майже втричі частіше (28,6 \% vs 10,4 \%, p=0,02), ніж у жінок (табл. 3 ).

Нами також були досліджені вікові особливості коронаросклерозу. Встановлено, що чоловіки порівняно 3 жінками мали більш виражене ураження BA (за значенням GS) як у віці до 65 років $(\mathrm{p}<0,001)$, так і після 65 років $(\mathrm{p}<0,01)$. У чоловічій популяції превалювали обструктивні ураження (до 65 років - 1 ВА, після 65 років - $\geq 3$ BA), у жіночій - інтактні судини (як до, так і після 65 років) (табл. 4). В обох групах хворих спостерігалося поступове прогресування коронарного атеросклерозу зі збільшенням віку: у чоловіків GS підвищився 310 (3,5-26) до 23 (9-55), p=0,045, а у жінок - 30 (0-5) до $0(0-20)$ балів, $\mathrm{p}=0,046$.

За локалізацією гемодинамічно вагомих стенозів ВА у хворих на стабільну IXC без перенесеного IM в анамнезі статистично значущих відмінностей серед представників обох статей не відзначалося. Так, в обох групах ВА за частотою

Таблиця 1

Демографічні, клінічні та лабораторні показники у порівнюваних групах

\begin{tabular}{|c|c|c|c|c|}
\hline \multicolumn{2}{|l|}{ Показники } & $\begin{array}{l}\text { Чоловіки } \\
(\mathrm{n}=70)\end{array}$ & $\begin{array}{l}\text { Жінки } \\
(\mathrm{n}=48)\end{array}$ & $\mathrm{p}$ \\
\hline \multicolumn{2}{|l|}{ Вік, років } & $63(58-71)$ & $66(60-70)$ & H3 \\
\hline \multicolumn{2}{|l|}{ Індекс маси тіла, кг/м² } & $29,73(26,26-32,11)$ & $31,6(29,05-34,5)$ & 0,022 \\
\hline \multicolumn{2}{|l|}{ Ожиріння, n (\%) } & $36(51,4)$ & $33(68,6)$ & н3 \\
\hline \multicolumn{2}{|l|}{ Гіпертонічна хвороба, n (\%) } & $69(98,6)$ & $47(97,9)$ & н3 \\
\hline \multirow{4}{*}{ ФК стабільної стенокардії, n (\%) } & $\mathrm{I}$ & 0 & $1(2,1)$ & \multirow{4}{*}{0,006} \\
\hline & II & $38(54,3)$ & $36(75)$ & \\
\hline & III & $32(45,7)$ & $9(18,8)$ & \\
\hline & IV & 0 & $2(4,2)$ & \\
\hline \multicolumn{2}{|l|}{ Серцева недостатність, n (\%) } & $70(100)$ & $47(97,9)$ & н3 \\
\hline \multirow{2}{*}{$\begin{array}{c}\text { Серцева недостатність } \\
\text { (за стадіями), n (\%) }\end{array}$} & $\mathrm{I}$ & $24(34,3)$ & $19(40,4)$ & \multirow{2}{*}{ н3 } \\
\hline & IIA & $46(65,7)$ & $28(59,6)$ & \\
\hline \multicolumn{2}{|l|}{ Цукровий діабет, n (\%) } & $29(41,4)$ & $17(35,4)$ & нз \\
\hline \multicolumn{2}{|l|}{ Глікемія натще, ммоль/л } & $6,2(5,4-7,7)$ & $5,9(5,2-6,8)$ & Н3 \\
\hline \multicolumn{2}{|l|}{ Загальний холестерин, ммоль/л } & $\begin{array}{c}4,9(4,1-5,8) \\
n=64\end{array}$ & $\begin{array}{c}5,4(4,3-6,1) \\
n=45\end{array}$ & н3 \\
\hline \multicolumn{2}{|c|}{$\begin{array}{c}\text { Швидкість клубочкової фільтрації (розрахована за } \\
\left.\text { формулою CKD-EPI), мл/(хв } \times 1,73 \mathrm{~m}^{2}\right)\end{array}$} & $77,20(62,92-86,73)$ & $70,95(62,52-85,45)$ & нз \\
\hline
\end{tabular}

Примітка. н3 - різниця показників статистично незначуща $(\mathrm{p}>0,05)$ 
Original research

Таблиця 2

Стан вінцевого русла у хворих на стабільну ішемічну хворобу серця без перенесеного інфаркту міокарда в анамнезі залежно від статі

\begin{tabular}{|c|c|c|c|}
\hline Стан вінцевого русла & $\begin{array}{c}\text { Чоловіки } \\
(\mathrm{n}=70)\end{array}$ & $\begin{array}{c}\text { Жінки } \\
(\mathrm{n}=48)\end{array}$ & $\mathrm{p}$ \\
\hline Інтактні ВА, $\mathrm{n}(\%)$ & $7(10)$ & $19(39,6)$ & \\
\hline Гемодинамічно незначущі стенози ВА, $\mathrm{n}(\%)$ & $8(11,4)$ & $10(20,8)$ & \multirow{2}{*}{$<0,001$} \\
\cline { 1 - 2 } Односудинне ураження, $\mathrm{n}(\%)$ & $19(27,1)$ & $5(20,8)$ & $5(10,4)$ \\
\hline Двосудинне ураження, $\mathrm{n}(\%)$ & $16(22,9)$ & $4(8,3)$ & \\
\hline Багатосудинне ураження, $\mathrm{n}(\%)$ & $20(28,6)$ & &
\end{tabular}

Таблиця 3

Тяжкість ураження вінцевого русла у паціснтів різних статевих груп зі стабільною ішемічною хворобою серця без перенесеного інфаркту міокарда в анамнезі

\begin{tabular}{|c|c|c|c|}
\hline Тяжкість ураження BA & $\begin{array}{c}\text { Чоловіки } \\
(\mathrm{n}=70)\end{array}$ & $\begin{array}{c}\text { Жінки } \\
(\mathrm{n}=48)\end{array}$ & $\mathrm{p}$ \\
\hline Відсутне $(\mathrm{GS}=0), \mathrm{n}(\%)$ & $7(10)$ & $19(39,6)$ & $<0,001$ \\
\hline Помірне $(\mathrm{GS}=1-32), \mathrm{n}(\%)$ & $43(61,4)$ & $24(50)$ & \\
\hline Тяжке $(\mathrm{GS}>32), \mathrm{n}(\%)$ & $20(28,6)$ & $5(10,4)$ & $<0,001$ \\
\hline $\mathrm{GS}$, б. & $13(5-44)$ & $4(0-16)$ & \multirow{2}{*}{} \\
\hline
\end{tabular}

Таблиця 4

Стан вінцевого русла в паціснтів чоловічої та жіночої статей зі стабільною ішемічною хворобою серця без перенесеного інфаркту мікарда в анамнезі віком до і понад 65 років

\begin{tabular}{|c|c|c|c|c|}
\hline \multirow{2}{*}{ Стан вінцевого русла } & \multicolumn{2}{|c|}{ Чоловіки } & \multicolumn{2}{|c|}{ Жінки } \\
\cline { 2 - 5 } & $\begin{array}{c}<65 \text { років } \\
(\mathrm{n}=39)\end{array}$ & $\begin{array}{c}\geq 65 \text { років } \\
(\mathrm{n}=31)\end{array}$ & $\begin{array}{c}<65 \text { років } \\
(\mathrm{n}=19)\end{array}$ & $\begin{array}{c}\geq 65 \text { років } \\
(\mathrm{n}=29)\end{array}$ \\
\hline Інтактні ВА, n (\%) & $5(12,8)$ & $2(6,5)$ & $10(52,6)$ & $9(31)$ \\
\hline Гемодинамічно незначущі стенози ВА, n (\%) & $5(12,8)$ & $3(9,7)$ & $3(15,8)$ & $7(24,1)$ \\
\hline Односудинне ураження, n (\%) & $12(30,8)$ & $7(22,6)$ & $3(15,8)$ & $7(24,1)$ \\
\hline Двосудинне ураження, n (\%) & $8(20,5)$ & $8(25,8)$ & $2(10,5)$ & $3(10,3)$ \\
\hline Багатосудинне ураження, n (\%) & $9(23,1)$ & $11(35,5)$ & $1(5,3)$ & $3(10,3)$ \\
\hline GS, б. & 10 & $\begin{array}{c}23 \\
(9-55)\end{array}$ & $\begin{array}{c}0 \\
(0-5)\end{array}$ & $\begin{array}{c}5 \\
(0-20)\end{array}$ \\
\hline
\end{tabular}

Таблиця 5

Локалізація стенозів вінцевих артерій у паціснтів з обструктивною ішемічною хворобою серця без перенесеного інфаркту міокарда в анамнезі залежно від статі

\begin{tabular}{|c|c|c|c|}
\hline Назва ВА & $\begin{array}{c}\text { Чоловіки } \\
(\mathrm{n}=55)\end{array}$ & $\begin{array}{c}\text { Жінки } \\
(\mathrm{n}=19)\end{array}$ & $\mathrm{p}$ \\
\hline ОС ЛВА, $\mathrm{n}(\%)$ & $9(16,4)$ & $2(10,5)$ & н3 \\
\hline ПМШГ ЛВА, $\mathrm{n}(\%)$ & $42(76,4)$ & $13(68,4)$ & н3 \\
\hline ОГ ЛВА, $\mathrm{n}(\%)$ & $25(45,5)$ & $8(42,1)$ & н3 \\
\hline ПВА, $\mathrm{n}(\%)$ & $34(61,8)$ & $8(42,1)$ & \\
\hline
\end{tabular}

Примітка. ОС ЛВА - основний стовбур лівої вінцевої артерії, ПМШГ ЛВА - передня міжшлуночкова гілка лівої вінцевої артерії, ОГ ЛВА - огинальна гілка лівої вінцевої артерії, ПВА - права вінцева артерія, нз - різниця показників статистично незначуща $(\mathrm{p}>0,05)$ 
Оригінальні дослідження

Таблиця 6

Статеві особливості локалізації уражень сегментів вінцевих артерій у хворих на обструктивну ішемічну хворобу серця без перенесеного інфаркту міокарда в анамнезі

\begin{tabular}{|c|c|c|c|}
\hline Уражені сегменти ВА & $\begin{array}{c}\text { Чоловіки } \\
(\mathrm{n}=55)\end{array}$ & $\begin{array}{l}\text { Жінки } \\
(\mathrm{n}=19)\end{array}$ & $\mathrm{p}$ \\
\hline $\begin{array}{c}\text { ПМШГ ЛВА, n (\%) } \\
\text { - проксимальний } \\
\text { - середній } \\
\text { - дистальний } \\
\end{array}$ & $\begin{aligned} 28 & (50,9) \\
21 & (38,2) \\
4 & (7,3)\end{aligned}$ & $\begin{array}{l}10(52,6) \\
7(36,8) \\
2(10,5)\end{array}$ & $\begin{array}{l}\text { H3 } \\
\text { H3 } \\
\text { H3 }\end{array}$ \\
\hline ДГ ЛВА, n (\%) & $7(12,7)$ & $2(10,5)$ & нз \\
\hline $\begin{array}{c}\text { ОГ ЛВА, n (\%) } \\
\text { - проксимальний } \\
\text { - середній } \\
\text { - дистальний }\end{array}$ & $\begin{array}{c}18(32,7) \\
6(10,9) \\
5(9,1)\end{array}$ & $\begin{array}{l}5(26,3) \\
2(10,5) \\
3(15,8)\end{array}$ & $\begin{array}{l}\text { H3 } \\
\text { H3 } \\
\text { H3 }\end{array}$ \\
\hline КГОА, n (\%) & $4(7,3)$ & $1(5,3)$ & н3 \\
\hline $\begin{array}{c}\text { ПВА, n (\%) } \\
\text { - проксимальний } \\
\text { - середній } \\
\text { - дистальний } \\
\end{array}$ & $\begin{array}{l}13(23,6) \\
19(34,5) \\
10(18,2) \\
\end{array}$ & $\begin{array}{c}5(26,3) \\
5(26,3) \\
1(5,3) \\
\end{array}$ & $\begin{array}{l}\text { H3 } \\
\text { H3 } \\
\text { H3 } \\
\end{array}$ \\
\hline ЗЛГ ПВА, n (\%) & $1(1,8)$ & 0 & H3 \\
\hline ЗМШГ ПВА, n (\%) & $4(7,3)$ & $1(5,3)$ & H3 \\
\hline
\end{tabular}

Примітка. ПМШГ ЛВА - передня міжшлуночкова гілка лівої вінцевої артерії, ДГ ЛВА - діагональна гілка лівої вінцевої артерії, ОГ ЛВА - огинальна гілка лівої вінцевої артерії, КГОА - крайова гілка огинальної артерії, ПВА - права вінцева артерія, ЗЛГ ПВА - задня латеральна гілка правої вінцевої артерії, ЗМШГ ПВА - задня міжшлуночкова гілка правої вінцевої артерії, н3 - різниця показників статистично незначуща (p>0,05)

ураження розташувалися таким чином: найчастіше виникала обструкція в ПМШГ ЛВА, за нею ПВА та ОГ ЛВА (табл. 5). Варто підкреслити, що в чоловіків спостерігалася тенденція до більш частого порівняно з жінками ураження ПВА, однак вона не досягла рівня статистичної значущостi $(\mathrm{p}=0,18)$.

Не менш важливим $є$ вивчення особливостей локалізації гемодинамічно вагомих стенозів за сегментами ВА, адже від цього залежать площа ішемізованого міокарда і вираженість клінічних проявів. Нами виявлено, що розташування обструктивних уражень сегментів ВА у чоловіків і жінок зі стабільною IXC без перенесеного IM в анамнезі не відрізнялося. У ПМШГ ЛВА і ОГ ЛВА вони найчастіше реєструвалися у проксимальній частині судини, тоді як у ПВА - у середній (табл. 6).

Результати нашого дослідження не суперечать даним світової медичної літератури. У низці робіт було виявлено статеві відмінності щодо основних анатомічних і патофізіологічних аспектів коронарного атеросклерозу. Так, наприклад, у великому ретроспективному дослідженні [14] за участі 14450 осіб, яким виконували коронарографію, показано, що гемодинамічно вагомі стенози ВА статистично значуще більш часто реєструвалися у чоловіків (86\% vs $64 \%, \mathrm{p}<0,001)$, тоді як інтактні ВА - у жінок (30,4 \% vs 5,6 \%, p<0,001). Також у представниць жіночої статі рідше було наявне обструктивне ураження ПВА (55,6\% vs $61,9 \%, \mathrm{p}<0,001)$ i ОГ ЛВА $(46,7 \%$ vs $50 \%$, $\mathrm{p}<0,01)$, однак фактична різниця у показниках становила лише кілька відсотків.

Дослідження Ezhumalai B. i Jayaraman B. [15], що охоплювало 500 жінок, яким виконували коронарографію, виявило, що в більшості 3 них (54,6 \%) були відсутні значущі звуження судин вінцевого русла. Найчастіше ураження локалізувалося в ПМШГ ЛВА, що цілком узгоджується 3 результатами нашої роботи.

Певними обмеженнями отриманих нами даних $є$ виконання дослідження в одному високоспеціалізованому центрі, відносно невелика кількість учасників, неможливість поширення результатів на інші групи хворих на IXC, зокрема на пацієнтів з постінфарктним кардіосклерозом.

\section{Висновок}

Жіночий патерн стабільної ішемічної хвороби серця характеризується частою відсутністю обструктивного ураження вінцевих артерій, поступовим прогресуванням атеросклеротичних змін вінцевого русла з віком, однак локалізація гемодинамічно вагомих звужень не відрізняється від такої у хворих чоловічої статі.

Перспективи подальших досліджень полягають у з'ясуванні стать-специфічних маркерів атеросклеротичного ураження ВА у хворих на стабільну IXC, що дозволить удосконалити алгоритми раннього виявлення захворювання, страти- 
Original research

фікації ризику та проведення своєчасних і належних профілактичних та лікувальних заходів.

Подяка. Успішному проведенню дослідження сприяло укладання угоди про науковотехнічне співробітництво між Національним медичним університетом імені О.О. Богомольця та ДУ «Інститут серця МОЗ України». Вважаємо своїм приємним обов'язком висловити щиру вдячність колективу ДУ «Інститут серця МОЗ України» за плідну співпрацю і цінну практичну допомогу.

Конфлікт інтересів. Автор заявляе про відсутність конфлікту інтересів, який міг би завдати шкоди неупередженості дослідження.

Джерела фінансування. Дослідження не отримало жодної фінансової підтримки від державної, громадської або комерційної організації.

\section{Список літератури}

1. Коваленко ВМ, Корнацький ВМ, редактори. Хвороби системи кровообігу як медико-соціальна і суспільнополітична проблема (аналітично-статистичний посібник). Київ; 2014. 280 с.

2. Оганов РГ, Масленникова ГЯ. Гендерные различия кардиоваскулярной патологии. Кардиоваскулярная терапия и профилактика. 2012;4:101-4.

3. Lawton JS. Sex and gender differences in coronary artery disease. Semin Thorac Cardiovasc Surg. 2011;23(2):12630 .

4. Stramba-Badiale M. Women and research on cardiovascular diseases in Europe: a report from the European Heart Health Strategy (EuroHeart) project. Eur Heart J. 2010;31:1677-81.

5. Wenger NK. Are we there yet? Closing the gender gap in coronary heart disease recognition, management and outcomes. Expert Rev Cardiovasc Ther. 2013;11(11):144750 .

6. Marzilli M, Merz CN, Boden WE, Bonow RO, Capozza PG, Chilian WM, et al. Obstructive coronary atherosclerosis and ischemic heart disease: an elusive link! J Am Coll Cardiol. 2012;60(11):951-6.

7. Pepine CJ, Ferdinand KC, Shaw LJ, Light-McGroary KA, Shah RU, Gulati M, et al. Emergence of nonobstructive coronary artery disease: a woman's problem and need for change in definition on angiography. J Am Coll Cardiol. 2015;66(17):1918-33.

8. Papakonstantinou NA, Stamou MI, Baikoussis NG, Goudevenos J, Apostolakis E. Sex differentiation with regard to coronary artery disease. J Cardiol. 2013;62(1):411.

9. Бугаенко ВВ. Гендерные особенности диагностики, течения и лечения ишемической болезни сердца. Український кардіологічний журнал. 2015;6:100-12.

10. Janion-Sadowska A, Sadowski M, Janion M. A female pattern of ischemic heart disease - a new look at an old problem. Przegl Lek. 2012;69(2):76-9.

11. Montalescot G, Sechtem U, Achenbach S, Andreotti F, Arden C, Budaj A, et al. 2013 ESC guidelines on the management of stable coronary artery disease: the Task Force on the management of stable coronary artery disease of the European Society of Cardiology. Eur Heart J. 2013;34(38):2949-3003.

12. Уніфікований клінічний протокол первинної, вторинної (спеціалізованої) та третинної (високоспеціалізованої) медичної допомоги «Стабільна ішемічна хвороба серця». [Інтернет].
[Цитовано 1 серпня 2017]. Доступно: http://moz.gov.ua/ docfiles/dn_20160302_0152dod.rar.

13. Gensini GG. A more meaningful scoring system for determining the severity of coronary heart disease. Am J Cardiol. 1983;51(3):606.

14. Giannoglou GD, Antoniadis AP, Chatzizisis YS, Damvopoulou E, Parcharidis GE, Louridas GE. Sex-related differences in the angiographic results of 14,500 cases referred for suspected coronary artery disease. Coron Artery Dis. 2008;19(1):9-14.

15. Ezhumalai B, Jayaraman B. Angiographic prevalence and pattern of coronary artery disease in women. Indian Heart J. 2014;66(4):422-6.

\section{References}

1. Kovalenko VM, Kornatskyi VM, editors. Khvoroby systemy krovoobihu yak medyko-sotsialna i suspilnopolitychna problema (analitychno-statystychnyi posibnyk) [Cardiovascular diseases as a medical, social and political problem (analytical and statistical manual)]. Kyiv; 2014. 280 p. (in Ukrainian).

2. Oganov RG, Maslennikova GJa. Gendernye razlichija kardiovaskuljarnoj patologii [Gender differences in cardiovascular pathology]. Kardiovaskuljarnaja terapija i profilaktika. 2012;4:101-4. (in Russian).

3. Lawton JS. Sex and gender differences in coronary artery disease. Semin Thorac Cardiovasc Surg. 2011;23(2):12630.

4. Stramba-Badiale M. Women and research on cardiovascular diseases in Europe: a report from the European Heart Health Strategy (EuroHeart) project. Eur Heart J. 2010;31:1677-81.

5. Wenger NK. Are we there yet? Closing the gender gap in coronary heart disease recognition, management and outcomes. Expert Rev Cardiovasc Ther. 2013;11(11):144750 .

6. Marzilli M, Merz CN, Boden WE, Bonow RO, Capozza PG, Chilian WM, et al. Obstructive coronary atherosclerosis and ischemic heart disease: an elusive link! J Am Coll Cardiol. 2012;60(11):951-6.

7. Pepine CJ, Ferdinand KC, Shaw LJ, Light-McGroary KA, Shah RU, Gulati M, et al. Emergence of nonobstructive coronary artery disease: a woman's problem and need for change in definition on angiography. J Am Coll Cardiol. 2015;66(17):1918-33.

8. Papakonstantinou NA, Stamou MI, Baikoussis NG, Goudevenos J, Apostolakis E. Sex differentiation with regard to coronary artery disease. J Cardiol. 2013;62(1):411.

9. Bugaenko VV. Gendernye osobennosti diagnostiki, techenija i lechenija ishemicheskoj bolezni serdca [Gender features of diagnosis, clinical course and treatment of ischemic heart disease]. Ukrainskyi kardiolohichnyi zhurnal. 2015;6:100-12. (in Russian).

10. Janion-Sadowska A, Sadowski M, Janion M. A female pattern of ischemic heart disease - a new look at an old problem. Przegl Lek. 2012;69(2):76-9.

11. Montalescot G, Sechtem U, Achenbach S, Andreotti F, Arden C, Budaj A, et al. 2013 ESC guidelines on the management of stable coronary artery disease: the Task Force on the management of stable coronary artery disease of the European Society of Cardiology. Eur Heart J. 2013;34(38):2949-3003.

12. Unifikovanyi klinichnyi protokol pervynnoi, vtorynnoi (spetsializovanoi) ta tretynnoi (vysokospetsializovanoi) medychnoi dopomohy «Stabilna ishemichna khvoroba sertsia» [Unified clinical protocol of primary, secondary (specialized) and tertiary (highly specialized) medical care «Stable ischemic heart disease»]. [Internet]. [Cited on 1 


\section{Оригінальні дослідження}

Aug 2017]. Available from: http://moz.gov.ua/docfiles/ dn_20160302_0152dod.rar. (in Ukrainian).

13. Gensini GG. A more meaningful scoring system for determining the severity of coronary heart disease. Am J Cardiol. 1983;51(3):606.

14. Giannoglou GD, Antoniadis AP, Chatzizisis YS, Damvopoulou E, Parcharidis GE, Louridas GE. Sex-related differences in the angiographic results of 14,500 cases referred for suspected coronary artery disease. Coron Artery Dis. 2008;19(1):9-14.

15. Ezhumalai B, Jayaraman B. Angiographic prevalence and pattern of coronary artery disease in women. Indian Heart J. 2014;66(4):422-6.

\section{Відомості про автора:}

Свінціцький Ігор Анатолійович - аспірант кафедри внутрішньої медицини №3 Національного медичного університету імені О.О. Богомольця, Київ, Україна.

\section{Сведения об авторе:}

Свинцицкий Игорь Анатольевич - аспирант кафедры внутренней медицины №3 Национального медицинского университета имени А.А. Богомольца, Киев, Украина.

Information about the author:

Igor Svintsitskyi $-\mathrm{PhD}$ student, $3^{\text {rd }}$ Department of Internal Medicine, Bogomolets National Medical University, Kyiv, Ukraine.

Надійила до редакиії 02.09.2017

Реиензент - проф. Федів O.I.

(C) I.A. Свінцุіцьький, 2017 